\title{
Correction to: Sleep Quality and Congestion with Breathe Right Nasal Strips: Two Randomized Controlled Trials
}

Michael J. Noss $\cdot$ Renee Ciesla $\cdot$ Gilbert Shanga

Published online: September 4, 2019

(c) The Author(s) 2019

Correction to: Adv Ther (2019) 36:1975-1985 https://doi.org/10.1007/s12325019-01005-5

The article "Sleep Quality and Congestion with Breathe Right Nasal Strips: Two Randomized Controlled Trials", written by Michael J. Noss, Renee Ciesla, and Gilbert Shanga, was originally published electronically on the publisher's internet portal (currently SpringerLink) on June 17, 2019 without Open Access. The article has now been made Open Access.

The original article can be found online at https://doi. org/10.1007/s12325-019-01005-5.

M. J. Noss ( $\square)$

Synexus (Formerly Radiant Research), Cincinnati, $\mathrm{OH}$, USA

e-mail: michaelnossmd@gmail.com

R. Ciesla

Clinical Development and Medical Affairs,

GlaxoSmithKline Consumer Healthcare, Warren,

NJ, USA

G. Shanga

Biostatistics Research and Development,

GlaxoSmithKline Consumer Healthcare, Warren,

NJ, USA
The copyright of the article changed to (c) The Author(s) 2019 and the article has been forthwith distributed under the terms of the Creative Commons Attribution-NonCommercial 4.0 International License (http://creativecommons.org/licenses/by-nc/4.0/), which permits any non-commercial use, distribution, and reproduction in any medium, provided you give appropriate credit to the original author(s) and the source, provide a link to the Creative Commons license, and indicate if changes were made.

The original article has been updated.

Open Access. This article is distributed under the terms of the Creative Commons Attribution-NonCommercial 4.0 International License (http://creativecommons.org/licenses/ by-nc/4.0/), which permits any noncommercial use, distribution, and reproduction in any medium, provided you give appropriate credit to the original author(s) and the source, provide a link to the Creative Commons license, and indicate if changes were made. 